\title{
Ownership of Management Rights to Reclamation Proceeds of Pt. Karya Citra Nusantara on the North Coast of Marunda
}

\author{
Supriyono \\ \{supriyono.afwa@yahoo.com\} \\ Univeristas Borobudur, Jakarta, Indonesia
}

\begin{abstract}
To overcome the limitations of land in every government and nongovernment area to reclamation. Reclamation is a process of reducing coastal areas into land areas. The area that does reclamation is usually a developing area such as Jakarta, one of which is the KCN reclamation on the north coast of Marunda whose designation is intended to create a port / terminal. Therefore, the Ministry of Transportation through the Port Authority participated in obtaining the authority to manage the $\mathrm{KCN}$ reclamation results on the north coast of Marunda. On the other hand, the Jakarta Regional Government has its own reference to get the authority to manage the reclaimed results of $\mathrm{KCN}$ on the north coast of Marunda. That raises the question of who is entitled to the management rights to the $\mathrm{KCN}$ reclamation on the north coast. Who holds the highest provisions in obtaining these management rights.
\end{abstract}

Keywords: reclamation; north coast; management rights

\section{Introduction}

The rapid development of the population in urban areas resulted in land supply in urban areas, especially Jakarta, to be limited. Land is a valuable asset to humans and is important for human life. This is because in addition to being one of the human needs of the land can also provide benefits economically. Land that can provide economic benefits is more focused on its use for the purpose of establishing building buildings in the form of housing, shops, offices, buildings, warehouses, factories, markets, malls, terminals and ports. Such use can provide benefits for the ruler / landowner.

Land can be controlled by Individuals, Government, State-Owned Enterprises, RegionalLy Owned Enterprises, Religious Entities, Social Agencies. Such ownership can be the status of Property Rights, Building Use Rights, Use Rights, and Management Rights.

Reclamation is one way to overcome the limited land. Reclamation is a process of reducing coastal areas into land areas. Reclamation is a condition that can occur in large urban areas in Indonesia to answer the needs of the land. Each region that does reclamation has different problems regarding the results of the reclamation.

As new land emerged, the land reclaimed by the coast was in state power. The emergence of new land as a result of coastal reclamation raises new problems in terms of its mastery. This 
mastery will have implications in its management rights. As stipulated in Management Rights are the right of control of the state whose implementation authority is partially delegated to the Holder of Management Rights, as according Government Regulation No. 18 of 2021 on Management Rights, Land Rights, Flat Units, and Land Registration. The management rights derived from State land are granted to Central Government Agencies, Local Government, State-Owned Enterprises/ Regionally Owned Enterprises, and State-Owned Legal Entities, according to the terms of the laws and regulations governing the Right of Management Entity/ RegionalLy Owned Legal Entity; Land Bank Agency; or a legal entity appointed by the Central Government. On the other hand, coastal reclamation can provide a new space for local governments to increase their local original income from land that emerges as a result of coastal reclamation.

PT. Kawasan Berikat Nusantara (Persero) is a State-Owned Enterprise that has a working business area in the form of sea and land areas in accordance with Presidential Decree No. 11 of 1992 in cooperation with PT. Karya Tehnik Utama (Private Company) by forming a joint venture company in the field of cooperation, namely PT. Karya Citra Nusantara is located in the Marunda Area of North Jakarta and contained in the cooperation agreement. Based on the cooperation, the reclamation location area will be issued Management Rights. The author is interested in raising the bar because the background mentioned above above theme with the title "Ownership of Management Rights over Reclamation Proceeds of PT. Karya Citra Nusantara on the North Coast of Marunda"

\section{Research Method}

In discussing the issues raised, the author will take a normative juridical approach where this approach is done by approaching the problem in terms of law, discussing then reviewing the literature materials in the form of books and laws and regulations related to the issues to be discussed.

The source of the data to be used in the results of this research is secondary data obtained from literature research that contains matters of a theoretical nature, principles, conceptions, attitudes and views or legal doctrines related to the issues discussedPrimary, secondary, and tertiary legal materials make up secondary data. It is also a support in the analysis and use of literature studies where the data collection process is used in this research by reading, studying, studying, recording and citing books, laws and regulations pertaining to the subject at hand.

\section{Analysis and Discussion}

\subsection{Land Rights Reclaimed}

Etymologically, reclamation comes from the English vocabulary "to reclaim" which means reclamation translates as the work of acquiring land. According to Law No. 1 of 2014 on Changes to Law No. 27 of 2007 on The Coastal Areas and Small Islands Management, Reclamation is an activity carried out by everyone in order to increase the environmental and socioeconomic benefits of land resources by land subsidy, drying, or drainage.

The area that is reclamation is the area that has developed. This is because reclamation requires considerable costs, and requires a decent area. Therefore, the area that performs 
reclmasi in the coastal area is so that the area becomes large and makes the income of the area increase. DKI Jakarta is one of the areas that developed into a region to develop business. The rapid population in Jakarta resulted in increasingly limited areas for shelter and business. Therefore reclamation is needed in Jakarta given the increasing number of Domestic investors and overseas investors competing in Jakarta so as to provide advantages in developing the region.

The objectives in the implementation of coastal reclamation shall comply with the regulations applicable in agrarian legislation. The implementation of reclamation must consider the impacts that can be caused by reclamation. One of them is the mastery of new land arising from the results of coastal reclamation.

The land tenure carried out by the State is described in Article 33 paragraph (3) of the Indonesian Constitution 1945, which states that the ground, water, and natural wealth contained within are controlled by the State and used for the greatest prosperity of the people. That is intended in the article to regulate the relationship between the State and the land, from the surface up to the wealth contained in the land whose power is held by the State and used for the prosperity of its people. which is further regulated in The Indonesian Law No. 5 of 1960 on the Basic Rules of Agrarian Trees.

Basically the legal status of land rights will give authority to people who are entitled to use and benefit from the land. Land rights are the control of the right to the outer part of the earth and give authority to the holder of his rights can use the intended land along with the earth's part of the water and the scope of space that is on it.

As discussed earlier, reclamation is an activity and activity that can be done from and by someone whose purpose is in order to increase the benefits of land resources or drainage, reclamation is basically to improve and / or utilize useless land to be useful, especially in areas and / or water or coastal areas. Especially in developed countries or in reclamation metropolitan areas aimed at expanding urban areas where land needs are increasingly needed.

Reclamation can produce new land that originally came from coastal areas or these aquatic areas were previously in the control of the State whose designation is for the benefit of the people. Therefore, the land rights resulting from reclamation for the coast are in the control of the State which must still be utilized as much as possible for the prosperity of the people.

One of the beach reclamation activities in Jakarta is in the Marunda area by PT. Karya Citra Nusantara which is a subsidiary of PT. Kawasan Berikat Nusantara (Persero) as a STATE-OWNED and PT. Main Technical Work from the private sector. The implementation of reclamation carried out by $\mathrm{KCN}$ is intended for the Port / terminal it causes a dispute for management rights between the Ministry of Transportation as the port organizer and the Regional Government of DKI Jakarta. Both the Ministry of Transportation and the Regional Government of DKI Jakarta each have regulations that become weapons of ownership of land management rights resulting from the rekmalasi of $\mathrm{KCN}$ beaches on the north coast of Marunda.

\subsection{Ministry of Transportation of Republic Indonesia}

Land Rights In this sub the author will explain the regulations that are the basis of the Ministry of Transportation to obtain the right to management of reclaimed land, namely:

a) Law No. 17 of 2008 on Shipping 
As mandated in Law No. 17 of 2008 on Shipping that government activities at the Port include the regulation and construction, supervision, and control of port activities; shipping safety and security; and/or customs; immigration; The quarantine of the port organizer is the Port Authority or the Port Organizing Unit. The Port Authority and the Port Organizing Unit act as government representatives to grant concessions or other forms to the Port Business Entity to conduct business activities at the Port as outlined in the agreement.

In the case of government activities at the Port, the Port Authority and the Port Organizing Unit are given the right to manage the land and utilization of the waters in accordance with the provisions of the legislation.

\section{b) Government Regulation No. 64 of 2015 on Changes to Government Regulation No. 61 of 2009 on Porting}

In this In the case of providing concessions to Port Business Entities through the auction process in line with the terms of the laws and regulations, or through assignment / appointment, the regulation mentions. The mechanism must comply with certain requirements, such as land owned by port business companies; and the investment must be undertaken solely by the Port Business Entity and not rely on public funds STATE BUDGET / APBD.

c) Regulation of the Minister of Transportation No. 15 of 2015 on Concessions and Other Forms of Cooperation between the Government and Port Business Entities in the Field of Port

The The construction of a new port, which is a type of cooperation between the government and port business entities, is carried out through concessions with an auction mechanism in accordance with the provisions of the legislation, or through assignment / appointment to the Port Business Entity. In the event of such an assignment / appointment, it must comply with the provisions, which include: land owned by the Port Business Entity; the investment is made wholly by the Port Business Entity and does not rely on funding from the Port Business Entity; and the investment is entirely made by the Port Business Entity and does not rely on funding from the Port Business Entity STATE BUDGET / APBD.

The land referred to above is handed over to the Port organizer as a management right before the concession agreement is signed, and against the Port Business Entity will be given the right to the management rights owned by the Port organizer in accordance with the provisions of the legislation.

As the authors have alluded to above, that ken reclamation is meant for terminals or ports. The above regulations mandate that management rights be granted to the Port Operator.

\subsection{Provincial Government of DKI Jakarta}

Currently, the Jakarta Regional Government has guidelines for reference in north coast reclamation, namely:

1. Presidential Decree No. 52 of 1995 on Reclamation of Jakarta Beach;

2. Presidential Regulation No. 54 of 2008 on Spatial Arrangement of Jabodetabekpunjur Area;

3. Presidential Regulation No. 112 of 2012 on Reclamation in Coastal Areas and Small Islands 
4. Law No. 1 of 2004 on The Management of Coastal Areas and Small Islands, which is a revision of Law No. 27 of 2007

The Jakarta Provincial Government has always made Presidential Decree No. 52 of 1995 as a reference. The article used is Article 4 which mentions the authority and reclamation of the north coast is in the Governor of DKI Jakarta. This regulation is what makes the Governor have the authority to issue reclamation permits.

Presidential Decree No. 52 of 1995 does not apply after presidential regulation No. 54 of 2008. "Presidential Decree No. 52 of 1995 does not apply due to reclamation related to spatial arrangement," Presidential Decree No. 52 of 1995. "Especially in Article 4, it says that the authority and responsibility of reclamation is in the Governor of DKI Jakarta.

Then there is Presidential Regulation No. 54 of 2008, not revoking the authority to grant permission by the Governor as stated in Presidential Decree No. 52 of 1995. The repealed regulations are about the layout. His authority and the license were not revoked. In Regional Regulation No. 8 of 1995 which is a derivative of Presidential Decree No. 52 of 1995 on Reclamation of Pantura Jakarta, which is contained in article 30, namely:

1. The reclaimed land area of Pantura Jakarta is granted management rights status to the Local Government.

2. The business of the right to be managed as referred to in paragraph (1) of this article is devolved by the Governor of the Regional Head to the Implementing Agency with the boundaries of the work area set by the Governor of Darerah.

3. By granting the establishment of Management Rights as referred to in paragraph (2) of this article, the Implementing Body is authorized to use reclaimed land to be selfcultivated or submit rights to reclaimed land to other parties in accordance with applicable laws and regulations.

Presidential Regulation No. 112 of 2012 on Reclamation in Coastal Areas and Small Islands mentioned that reclamation implementation permits must be authorized by the Ministry of Marine Affairs and Fisheries. Presidential Regulation No. 112 of 2012 is a derivative of Law No. 27 of 2007 on "Regulation of the Minister of Marine Affairs and Fisheries," which was later revised with Law No. 1 of 2014.

On that basis, the authority of the north coast reclamation permit can only be issued by the Governor of DKI after a recommendation from the Minister of Marine Affairs and Fisheries. In addition, the permit for the implementation of north coast reclamation can only be issued by the Governor after there is a Coastal Area Zoning Regulation.

\subsection{Management Rights over KCN Reclamation Results on The North Coast of Marunda}

On top of the author has outlined the provisions of the regulations that each became a reference for the Ministry of Transportation and the Regional Government of DKI Jakarta to get management rights for the results of kcn reclamation on the north coast of Marunda. That the statutory provisions on which the DKI Jakarta Regional Government is based are lower than the statutory provisions used by the Ministry of Transportation (Port Authority / Port Organizer). In such case the legal principle of les superior de rogat lex inverior means that higher regulations negate or eliminate lower regulations.

Therefore, in the opinion of the author of the Ministry of Transportation (Port Authority / Port Organizer) who gets the right to manage the results of reclamation if the land produced by the reclamation is intended as a public port / public terminal. 


\section{Conclusion}

Based on the discussions mentioned above, the author concluded that reclamation was carried out to cause new land whose control was in the control of the State for the benefit of the people. But the provisions on reclamation raise the question of who has the right to manage the results of the KCN reclamation on the north coast.

That the implementation of KCN reclamation on the north coast of Marunda is intended for the construction of the Port / terminal which raises the question of whether the ministry of transportation through Law No. 17 of 2008 on Shipping is entitled to the right of management of the results of the $\mathrm{KCN}$ reclamation given that the Law mandates that every government activity in the Port its management rights be granted to the Port organizers.

On the other hand, the Local Government has its own reference to get the authority of the management rights of north coast reclamation results. Both have laws and regulations that are the basis for obtaining the authority of management rights. Therefore in the opinion of the author in this case applies the legal principle les superior de rogat lex inverior which means higher regulations negate or get rid of lower regulations.

\section{References}

[1] Government Regulation No. 18 of 2021 on Management Rights, Land Rights, Flat Units, and Land Registration

[2] Law No. 1 of 2014 on Amendments to Law No. 27 of 2007 on The Management of Coastal Areas and Small Islands

[3] Maria SW Sumardjono, 2008, Land in Perspective of Social and Cultural Economic Rights, Kompas, Jakarta

[4] Presidential Decree No. 52 of 1995 on Reclamation of Jakarta Beach;

[5] Presidential Regulation No. 54 of 2008 on Spatial Arrangement of Jabodetabekpunjur Area;

[6] Presidential Regulation No. 112 of 2012 on Reclamation in Coastal Areas and Small Islands;

[7] Law No. 1 of 2004 on The Management of Coastal Areas and Small Islands, which is a revision of Law No. 27 of 2007 